\title{
Assessment of Quantitative Traits of Rajma Bean (Phaseoulus vulgaris L.) Accessions for Yield and Yield Attributing Traits in Multi-Environments of Nepal
}

\author{
Darai R ${ }^{1 *}$, Sah R1, Sah J B², Gupta B ${ }^{3}$ and Rasaili $\mathbf{S}^{2}$ \\ ${ }^{1}$ Coordinator/ Senior Scientist and STO, Grain Legumes \\ Research Program, Nepal \\ ${ }^{2}$ Directorate of Agricultural Research, Nepal \\ 3J ute Research Program, Itahari, Nepal \\ *Corresponding author: Rajendra Darai, \\ Coordinator/Senior Scientist and STO, Grain Legumes \\ Research Program, Khajura, Nepal
}

Received: March 01, 2021; Accepted: March 24, 2021; Published: March 31, 2021

\begin{abstract}
Rajma (Phaseolus vulgaris $L$ ) known as the common bean, French bean, kidney bean, bush bean, and pole bean is the most important grain legume of Nepal which covers about 10,529 ha areas along with the productivity of $1477 \mathrm{kgha}^{-1}$. Generally it is grown during summer in mid/high hills and during winter (post rainy) season interai/inner terai in rice and maize based eco-system. Now Rajma bean is being popular as the cash crop in the province 3, 5 and 6 because of producing organic products and tastier quality. Multi-environment trials was carried out at Nepalgunj, Parwanipur, Itahari and Surkhet during the winter season of 2014-2017 comprised of 10 diverse Rajma genotypes in Randomized Complete Block Design with three replications in order to evaluate the quantitative variation with respect to yield and yield contributing traits. The combined analysis of variance showed that the highly significant differences among the genotypes and locations in the traits like days to flowering, days to maturity, plant height, hundred seed weight and grain yield. However; there was not any GxE interaction effect found in days to flowering, days to maturity and grain yield. Mean yield performances showed that the genotype PDR-14 $\left(2341 \mathrm{kgha}^{-1}\right)$ produced the highest yield followed by Utkarsh $\left(2332 \mathrm{kgha}^{-1}\right)$ and Arun-2 (2021 $\left.\mathrm{kgha}^{-1}\right)$. In conclusion, PDR-14 gave 9-56\% higher yield among the genotypes and its stability analysis test also indicated that PDR-14 was found a highly stable across the environments and over the years. Variegated red kidney shape seed, white flowers along with dwarf and glabrous leaf pubescence is the DUS trait of the PDR-14 and recommended for terai/inner terai to high hills.
\end{abstract}

Keywords: Component traits; Environments Rajma bean; Quantitative; Variation

\section{Introduction}

Rajma is an important legume known as Common bean, French bean, Kidney bean, bush bean, and pole bean. In many developing countries, common bean (Phaseolus vulgaris L.) are being grown for vegetables and pulses in diverse cropping system. The common bean is a self-pollinated species belonging to the Fabaceae family and is the most important sources of the protein [1]. A high number of small land holding farmers with low incomes usually adopted to produce the crop. In Nepal, it is cultivated an areas of about 10,529 ha with the productivity $1477 \mathrm{~kg} / \mathrm{ha}$ and being popular as the cash crop in the Gandaki province, province 5 and Karnali province. It grows as a summer crop in mid/high hills \& winter crop in terai/inner terai. The high genetic diversity found in African, Asian and European germplasm has suggested the possibility that those continents could be considered as other centers of genetic diversity for common bean [2]. It is an important legume crop cultivated in a wide range of agroclimatic conditions from Tarai (91m amsl) to high hill (2500m amsl) of Nepal, especially in mountain districts such as Jumla, Humla, Mustang, Rasuwa, Solukhumbu, etc., where mixed landraces with varying morphologies are cultivated. Nepal's hills and mountains are rich in bean diversity, and some landraces have unique characteristics $[3,4]$. In general, common beans grown in high-hill have better taste and are considered more nutritious compared to the beans grown in Terai region of Nepal. More recently, this crop is commonly grown along with kidney bean, fetches good return and have well established market [5-8]. In these days, area of phaseols bean is in increasing trends due to its good market potential along with good returns. This bean is being popular in Jumla and periphery districts of Karnali province known as Jumla's organic bean gift (Jumlako Kosheli) in the Nepalgunj and Kathmadu big marts. The main objective of the study was in order to evaluate the quantitative variation with respect to yield and yield contributing traits. In terai region of Nepal, Rajma has been cultivating in winter season. Till date, there is not anyone Rajma variety released/registered for the farmers cultivation. One of the mandated organizations for legumes research, GLRP, Khajurahas prepared the variety development program in collaboration with NARC satellite stations.

\section{Materials and Methods}

In Coordinated Varietal Trial (CVT); A total of 10 genotypes namely PDR-14, Amber, Utkarsha, Arun-2, BL-63, Kanpur, Chitra NL-1, Pant-1and Pant-2 were evaluated in 2015 at RARS, Parwanipur and GLRP, Khajura, in 2016 at JRP, Ithari; GLRP, Khajura; ARS, Surkhet and RARS, Parwanipur, same as in 2017 at GLRP, Khajura [9-11]. Trial was conducted in Randomized Completely Block Design 
Table 1: Performance of Rajma genotypes in MLT at RARS, Parwanipur, 2015.

\begin{tabular}{|c|c|c|c|c|c|c|c|c|}
\hline S. No & Genotypes & DF & DM & $\begin{array}{c}\text { PLHT } \\
\mathbf{( c m})\end{array}$ & PP & SP & $\begin{array}{c}\text { GY } \\
(\mathbf{K g} / \mathbf{h a})\end{array}$ & $\begin{array}{c}\text { HSWT } \\
\mathbf{( g )}\end{array}$ \\
\hline 1 & PDR 14 & $54 \mathrm{~b}$ & $112 \mathrm{~b}$ & $30 \mathrm{c}$ & 11 & 3 & $966.0 \mathrm{abcd}$ & $39.8 \mathrm{a}$ \\
\hline 2 & Amber & $50 \mathrm{c}$ & $109 \mathrm{c}$ & $29 \mathrm{c}$ & 11 & 4 & $855.3 \mathrm{~cd}$ & $35.6 \mathrm{~cd}$ \\
\hline 3 & Utkars & $64 \mathrm{a}$ & $115 \mathrm{a}$ & $46 \mathrm{a}$ & 13 & 4 & $1079.3 \mathrm{ab}$ & $29.3 \mathrm{e}$ \\
\hline 4 & Arun-2 & $54 \mathrm{~b}$ & $112 \mathrm{~b}$ & $42 \mathrm{ab}$ & 12 & 4 & $1150.0 \mathrm{a}$ & $39.1 \mathrm{a}$ \\
\hline 5 & Bl-63 & $50 \mathrm{c}$ & $109 \mathrm{c}$ & $26 \mathrm{c}$ & 10 & 3 & $888.0 \mathrm{bcd}$ & $36.9 \mathrm{bc}$ \\
\hline 6 & Kanpur & $54 \mathrm{~b}$ & $112 \mathrm{~b}$ & $39 \mathrm{~b}$ & 11 & 4 & $769.3 \mathrm{~d}$ & $35.1 \mathrm{~d}$ \\
\hline 7 & Chitra & $50 \mathrm{c}$ & $109 \mathrm{c}$ & $25 \mathrm{c}$ & 11 & 4 & $892.7 \mathrm{bcd}$ & $36.6 \mathrm{bcd}$ \\
\hline 8 & Nl-1 & $50 \mathrm{c}$ & $109 \mathrm{c}$ & $26 \mathrm{c}$ & 44 & 4 & $1026.7 \mathrm{abc}$ & $38.1 \mathrm{ab}$ \\
\hline & Mean & 53.5 & 110.8 & 33.04 & 15 & 4 & 953.4 & 36.3 \\
\hline & P-value & $0.000^{* *}$ & $0.000^{* *}$ & $0.000^{* *}$ & 0.48 & 0.55 & $0.039^{*}$ & $0.000^{* *}$ \\
\hline & F-Value & 0 & 99.6 & 26.93 & 1 & 1 & 3 & 33.9 \\
\hline & CV\% & 0 & 0.38 & 8.34 & 132 & 6 & 13.3 & 2.6 \\
\hline & LSD & 0 & 0.75 & 4.82 & & & 222.1 & 1.7 \\
\hline
\end{tabular}

in $4 \times 3.6=14.4 \mathrm{~m}^{2}$ plot size with three replications. The plant geometry, row-to-row space was maintained as $40 \mathrm{~cm}$ and plant to plant $10 \mathrm{~cm}$. Recommended dose of fertilizer 100:60:40 kg NPK/ha was applied, full dose of phosphorus and potash and half dose of nitrogen applied during field preparation and remaining half dose of nitrogen was top dressed after 20-30 days after sowing. During the intervention period, precision agronomic packages were followed and appropriate pesticides and insecticides were applied as per the requirements. Data on agro-morphological traits, yield and yield components were collected and data was analyzed using META-R and R-Stat Version 3.2.

\section{Results}

At Parwanipur 2015, the results of analysis of variance showed statistically highly significant differences among the genotypes in the agronomic traits days to $50 \%$ flowering, days to maturity, plant height, grain yield and 100 seed weight. Genotypes Arun 2 (11500kg/ ha) and Utkars (1079kg/ha) were produced better yield among the tested genotypes in Table 1. Likely in khajura, the results of analysis of variance (Table 2) revealed that genotypes were statistically

Table 2: Mean data on phenology growth and Yield of MLT, GLRP, Khajura, 2015.

\begin{tabular}{|c|c|c|c|c|c|c|}
\hline S. No & Genotypes & PLHT (cm) & PP & SP & GY (Kg/ha) & HSWT(g) \\
\hline 1 & PDR 14 & 37 & 7 & 4 & 518 & 33 \\
\hline 2 & Amber & 35 & 7 & 3 & 425 & 35 \\
\hline 3 & Utkars & 39 & 6 & 5 & 465 & 30 \\
\hline 4 & Arun-2 & 48 & 7 & 5 & 542 & 35 \\
\hline 5 & Bl-63 & 33 & 7 & 4 & 515 & 33 \\
\hline 6 & kanpur & 36 & 7 & 4 & 437 & 34 \\
\hline 7 & Chitra & 36 & 6 & 4 & 430 & 36 \\
\hline 8 & Nl-1 & 43 & 8 & 3 & 563 & 38 \\
\hline & Mean & 38 & 7 & 4 & 487 & 34 \\
\hline & P-value & 0 & 1 & 0.00 & 1 & 0.00 \\
\hline & F-Value & 0.98 & 0.7 & 2 & 0.16 & 1.2 \\
\hline & CV\% & 21.6 & 18.4 & 16.31 & 18.49 & 10.15 \\
\hline
\end{tabular}

Table 3: Mean data on phenology, growth and yield of MLT, GLRP, Khajura, 2016

\begin{tabular}{|c|c|c|c|c|c|c|c|c|}
\hline S. No & Genotypes & DF & DM & PLHT & PP & SP & $\begin{array}{c}\text { HSWT } \\
(\mathbf{g})\end{array}$ & $\begin{array}{c}\text { GY } \\
\text { (Kg/ha) }\end{array}$ \\
\hline 1 & PDR-14 & 46 & 108 & 47 & 37 & 3.5 & 42 & 2471 \\
\hline 2 & Amber & 45 & 112 & 4 & 12 & 4.1 & 40 & 1938 \\
\hline 3 & Utkarsh & 46 & 112 & 55 & 11 & 3.5 & 37 & 2600 \\
\hline 4 & Arun-2 & 52 & 110 & 70 & 10 & 3.6 & 47 & 1579 \\
\hline 5 & BL-63 & 44 & 105 & 44 & 10 & 3.6 & 41 & 1517 \\
\hline 6 & Kanpur & 45 & 110 & 46 & 11 & 4.3 & 40 & 1783 \\
\hline 7 & Chitra & 44 & 100 & 39 & 10 & 3.2 & 39 & 1358 \\
\hline 8 & NL-1 & 43 & 95 & 44 & 10 & 3.3 & 41 & 1842 \\
\hline 9 & Pant-1 & 45 & 110 & 74 & 10 & 3.9 & 42 & 1983 \\
\hline & Mean & 46 & 107 & 51.7 & 13 & 3.7 & 41 & 1897 \\
\hline & P-Value & 0.4 & $<0.001$ & $<0.001$ & 0.46 & 0.181 & 0.002 & 0.05 \\
\hline & CV\% & 10.27 & 1.1 & 10 & 116.6 & 13 & 4.8 & 23.9 \\
\hline & LSD & NS & $2.1 *$ & $8.9 *$ & NS & NS & $3.4_{* *}$ & $*$ \\
\hline & & & & & & & $*$ \\
\hline
\end{tabular}

Table 4: Mean data on phenology and growth and Yield of MLT, JRP, Itahari, 2016.

\begin{tabular}{|c|c|c|c|c|c|c|c|}
\hline S. No & Genotypes & DF & DM & PLHT & PP & SP & GY (Kg/ha) \\
\hline 1 & PDR-14 & 76 & 122 & 31 & 15 & 4 & 1412 \\
\hline 2 & Amber & 75 & 122 & 31 & 17 & 4 & 1121 \\
\hline 3 & Utkarsh & 82 & 121 & 33 & 16 & 4 & 1625 \\
\hline 4 & Arun-2 & 76 & 119 & 30 & 15 & 4 & 1396 \\
\hline 5 & BL-63 & 75 & 103 & 22 & 12 & 4 & 1046 \\
\hline 6 & Kanpur & 75 & 109 & 30 & 11 & 4 & 892 \\
\hline 7 & Chitra & 76 & 103 & 22 & 9 & 4 & 975 \\
\hline 8 & NL-1 & 75 & 105 & 23 & 12 & 4 & 896 \\
\hline & Mean & 76 & 113 & 28 & 13 & 4 & 1170 \\
\hline & P-Value & $<0.001^{* *}$ & $<0.001^{* *}$ & $<0.001^{* *}$ & 0.08 & 0.44 & $0.03^{*}$ \\
\hline & CV\% & 1.3 & 0.8 & 8.3 & 25.5 & 9.6 & 23.1 \\
\hline & LSD & $1.8^{* *}$ & $1.5^{* *}$ & $4.0^{* *}$ & NS & NS & $473.6^{*}$ \\
\hline
\end{tabular}

significant differences in the parameters like plant height, seed per pod and hundred seed weight. Genotype NL1 (563kg/ha), and Arun-2 $(542 \mathrm{~kg} / \mathrm{ha})$ were produced the highest yield among tested genotypes. NL-1 had a bolder seed (38g/100 seed). In 2016, at GLRP, Khajura data (Table 3) revealed that the genotypes were highly significant in days to maturity, plant height, and seed weight. Genotype Utkarsh produced the highest yield (2600kg/ha) followed by, PDR-14 $(2471 \mathrm{~kg} /$ ha) and Pant-1 (1983kg/ha). Arun-2 showed the highest seed weight (47g/100 seed). Same as in 2016, JRP, Ithari data showed that the genotypes were highly significant in days to $50 \%$ flowering, days to maturity and plant height and significant in grain yield. Genotype Utkarsh produced the highest yield $(1625 \mathrm{~kg} / \mathrm{ha})$ followed by, PDR$14(1412 \mathrm{~kg} / \mathrm{ha})$ in Table 4 . Data (Table 5) illustrated that genotypes were statistically significant difference in the parameters like days to maturity, plant height, and hundred seed weight. Genotype Amber (3146kg/ha) produced the highest yield followed by Arun-2 (3090kg/ ha) and Utkarsh (2986kg/ha). Arun-2 had a bolder seed (44g/100 seed). In 2016, RARS, Parwanipur data analysis of variance showed that the genotypes were highly significant difference in days to 
Table 5: Mean data on phenology growth and Yield of MLT, ARS, Surkhet, 2016.

\begin{tabular}{|c|c|c|c|c|c|c|c|}
\hline S. No & Genotypes & DTF & DTM & PH & PPP & HGW & GY (Kg/ha) \\
\hline 1 & PDR-14 & 47 & 114 & 48 & 22 & 40 & 2701 \\
\hline 2 & Amber & 44 & 122 & 50 & 21 & 40 & 3146 \\
\hline 3 & Utkarsh & 57 & 123 & 124 & 18 & 33 & 2986 \\
\hline 4 & Arun-2 & 46 & 121 & 106 & 20 & 44 & 3090 \\
\hline 5 & BL-63 & 46 & 110 & 36 & 17 & 39 & 2417 \\
\hline 6 & Kanpur & 47 & 120 & 45 & 16 & 40 & 2319 \\
\hline 7 & Chitra & 44 & 111 & 46 & 15 & 40 & 2583 \\
\hline 8 & NL-1 & 42 & 108 & 45 & 14 & 39 & 2970 \\
\hline & Mean & 46 & 116 & 63 & 18 & 40 & 2777 \\
\hline & P-Value & $<0.001^{* *}$ & 0.05 & $<0.001^{* *}$ & 0.36 & $0.018^{*}$ & 0.05 \\
\hline & CV\% & 4.4 & 5.4 & 15.5 & 25 & 6.8 & 13.3 \\
\hline & LSD & 3.6 & NS & 17.0 & NS & 4.7 & NS \\
\hline
\end{tabular}

Table 6: Mean data on phenology growth and Yield of MLT, RARS, Parwanipur, 2016

\begin{tabular}{|c|c|c|c|c|c|c|c|c|}
\hline S. No & Genotypes & DF & DTM & PH & PPP & SPP & $\begin{array}{c}\text { HSWT } \\
(\mathbf{g})\end{array}$ & $\begin{array}{c}\text { GY } \\
(\mathbf{K g} / \mathbf{h a})\end{array}$ \\
\hline 1 & PDR-14 & 54 & 117 & 36 & 15 & 6 & 50 & 1369 \\
\hline 2 & Amber & 54 & 121 & 32 & 19 & 6 & 44 & 1256 \\
\hline 3 & Utkarsh & 62 & 121 & 75 & 14 & 7 & 48 & 1538 \\
\hline 4 & Arun-2 & 52 & 118 & 68 & 14 & 7 & 52 & 1070 \\
\hline 5 & BL-63 & 55 & 115 & 33 & 14 & 7 & 43 & 1015 \\
\hline 6 & Kanpur & 57 & 116 & 40 & 11 & 7 & 46 & 828 \\
\hline 7 & Chitra & 52 & 115 & 33 & 12 & 7 & 42 & 789 \\
\hline 8 & NL-1 & 54 & 114 & 34 & 15 & 6 & 42 & 868 \\
\hline & Mean & 55 & 117 & 44 & 14 & 7 & 46 & 1092 \\
\hline & P-Value & 0.001 & $<0.001$ & $<0.001$ & 0.11 & 0.58 & $<0.001$ & 0.006 \\
\hline & CV\% & 3.8 & 1 & 13.3 & 20.4 & 10.5 & 0.8 & 19.8 \\
\hline & LSD & $3.7^{* *}$ & $2.0^{* *}$ & $10.3^{* *}$ & NS & NS & $3.2^{* *}$ & $378.9^{*}$ \\
\hline
\end{tabular}

flowering, days to maturity, plant height, grain yield and seed weight. Genotype Utkarsh produced the highest yield (1538kg/ha) followed by, PDR-14 (1369kg/ha) and Amber (1256kg/ha). Same as previous Arun-2 had the highest seed weight (52g/100 seed) in Table 6 . Likely in the year of 2017, GLRP, Khajura data analysis of variance revealed that the genotypes were significantly difference $(<0.005)$ in days to $50 \%$ flowering, days to maturity, plant height, seed per pod and yield $\mathrm{kg} / \mathrm{ha}$. Genotype PDR-14produced the highest yield $(2319 \mathrm{~kg} / \mathrm{ha})$ followed by, Utkarsh (1992kg/ha) and BL-63 (1878kg/ha) in Table 7.Combinedmean analysis of variance showed that genotypes were significantly different in days to maturity, plant height and yield parameters across the locations over the years (2015-2017).

G $x$ E interaction in GGE biplots in Figure 1 illustrated that based on both mean and stability the best genotype was Amber then followed by PDR-14. In Figure 2 base on concentric ring the ideal genotype was BL-63 however according to Figure 3 Ithari was seen the best environment. In Figure 4, genotype Amber and Chitra were found ideal and vertex to Khanjra and Surkhet environments, while NL-1 and PDR-14 were ideal for Parwanipur and BL-63, Utkarsh, Kanpur-1 and Arun 2 were found ideal for Ithari environment.
Table 7: Performance of Rajma Genotype in MLTGLRP, Khajura 2017.

\begin{tabular}{|c|c|c|c|c|c|c|c|}
\hline EN & Genotypes & DF & DM & PIht & PP & SP & GY \\
\hline 1 & PDR 14 & 40 & 104 & 20 & 11 & 4 & 2319 \\
\hline 2 & Amber & 40 & 107 & 13 & 14 & 5 & 1329 \\
\hline 3 & Utkarsh & 54 & 106 & 21 & 10 & 5 & 1992 \\
\hline 4 & Arun-2 & 36 & 103 & 27 & 9 & 4 & 1722 \\
\hline 5 & BL63 & 35 & 90 & 16 & 12 & 5 & 1878 \\
\hline 6 & Kanpur & 34 & 104 & 13 & 8 & 5 & 822 \\
\hline 7 & Chitra & 34 & 91 & 14 & 10 & 5 & 1715 \\
\hline 8 & NL-1 & 34 & 89 & 15 & 11 & 4 & 1503 \\
\hline 9 & Pant-1 & 40 & 107 & 27 & 11 & 5 & 1725 \\
\hline 10 & Pant-2 & 35 & 99 & 19 & 8 & 5 & 1430 \\
\hline & Mean & 38 & 100 & 19 & 10 & 5 & 1644 \\
\hline & P-value & $<0.001$ & $<0.001$ & $<0.001$ & 0.300 & $<0.001$ & 0.025 \\
\hline & CV\% & 3.13 & 2.33 & 17.45 & 26.34 & 6.55 & 25.14 \\
\hline & LSD & 2.05 & 3.99 & 5.55 & 4.71 & 0.53 & 708.86 \\
\hline
\end{tabular}

Table 8: Combined analysis Rajma MLT across the location over the years (2015-2017).

\begin{tabular}{|c|c|c|c|c|c|c|c|c|}
\hline S. No & Genotypes & DF & DM & PLHT & PP & SP & $\begin{array}{c}\text { HSWT } \\
(\mathbf{g})\end{array}$ & $\begin{array}{c}\text { GY } \\
(\mathbf{K g} / \mathbf{h a})\end{array}$ \\
\hline 1 & PDR-14 & 58 & 119 & 39 & 18 & 4 & 43 & $1862 \mathrm{a}$ \\
\hline 2 & Arun-2 & 60 & 119 & 46 & 16 & 4 & 44 & $1433 \mathrm{ab}$ \\
\hline 3 & Chitra & 59 & 116 & 36 & 14 & 4 & 39 & $1478 \mathrm{abc}$ \\
\hline 4 & Amber & 58 & 121 & 37 & 17 & 4 & 41 & $1666 \mathrm{bcd}$ \\
\hline 5 & BL-63 & 53 & 116 & 30 & 14 & 4 & 40 & $1300 \mathrm{bcd}$ \\
\hline 6 & NL-1 & 52 & 111 & 31 & 16 & 4 & 35 & $1202 \mathrm{~d}$ \\
\hline 7 & Kanpur & 63 & 121 & 42 & 19 & 4 & 40 & $1250 \mathrm{~cd}$ \\
\hline 8 & Utkarsh & 62 & 120 & 37 & 14 & 4 & 40 & 1698 \\
\hline & Mean & 59 & 118 & 37 & 17 & 4 & 40 & 1474 \\
\hline & P-value & & & & & & & \\
\hline & Env & $<0.001$ & $<0.001$ & $<0.001$ & 0.500 & 0.100 & $<0.001$ & $<0.001$ \\
\hline & Gen & 0.260 & 0.020 & 0.004 & 0.500 & 0.420 & 0.001 & 0.018 \\
\hline & Year & 0.190 & 0.020 & $<0.001$ & 0.120 & 0.300 & $<0.001$ & $<0.001$ \\
\hline & GXE & 0.990 & 0.120 & 0.900 & 0.330 & 0.700 & 0.600 & 0.99 \\
\hline & LV $\%$ & 13.00 & 5.2 & 27 & 31 & 11 & 12 & 31 \\
\hline & LSD & & & & & & & 416.77 \\
\hline
\end{tabular}

\section{Discussion}

Beans are consumed as whole seeds as vegetable or split forms, both as soup or 'daal'. Beans contains healthy proteins, are consumed by all households. Indeed, black bean soup is given to their sick people as an energy supplement. Farmers in Nepal preferred bean landraces that are medium growth habit, early maturing nature, high yielding, good seed size and color and are high demand in the market [5,12]. A similar study was done in bean growing area in Malawi to understand the farmer's specifications for variety selection showed that farmers looked on grain color, cooking time, taste, grain size as well as grain brightness to choose the varieties [13]. Stoilova et al. [14] found that out of many accessions studied, some accessions with an erect habit, a shorter period to reach maturity had higher number of pods and seeds 


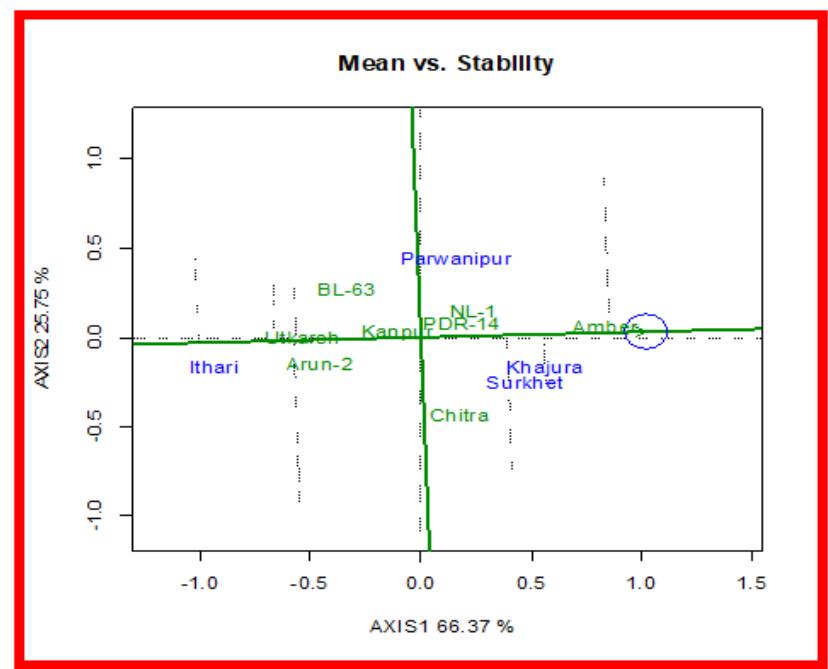

Figure 1: Genotypes mean vs. stability.

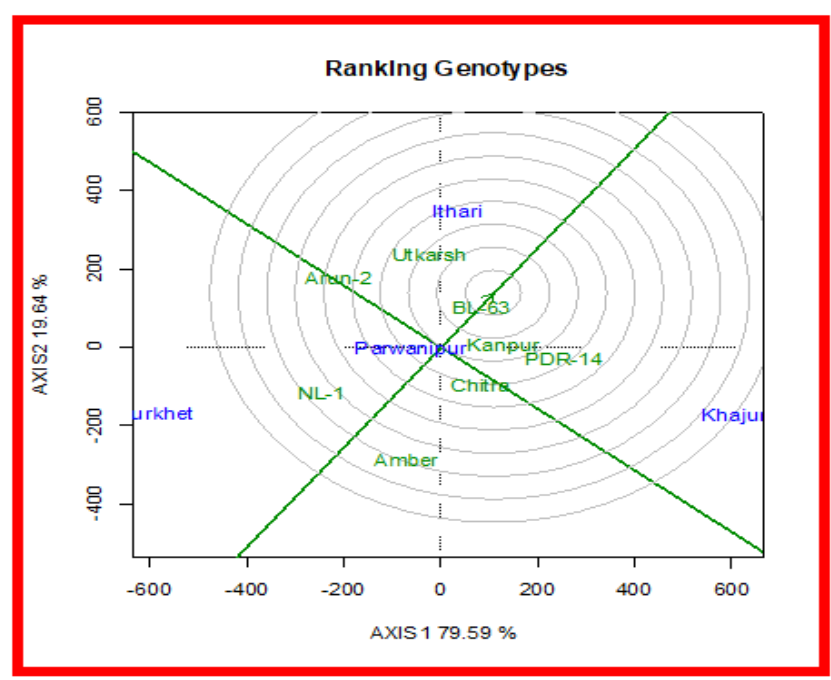

Figure 2: Ranking of genotypes based on genotype performance and stability.

per plant as these genotypes escaped unfavorable conditions of high daily temperature and low humidity during the flowering and pod formation periods. In the study, the genotypes had different flowering and pod maturity times even they were planted on the same date. Flowering and pod maturity occurred earliest for all the varieties in the khajura and surkhet than Itahari and Parwanipur site. This flowering data clearly indicated the environment particularly the temperature played an important role in physiological and phenological growth of the varieties included in the study. Similar results of common bean landraces at Mexico showed there were significant differences in the morphological and physiological traits of the plant, pod and grain among different geographic regions which were also associated with different indigenous groups [15]. There was effect of genotype by environment interaction on the bean genotypes and yield traits. Some lines showed vertex that mean they were location specific while some lines were highly stable across the locations.

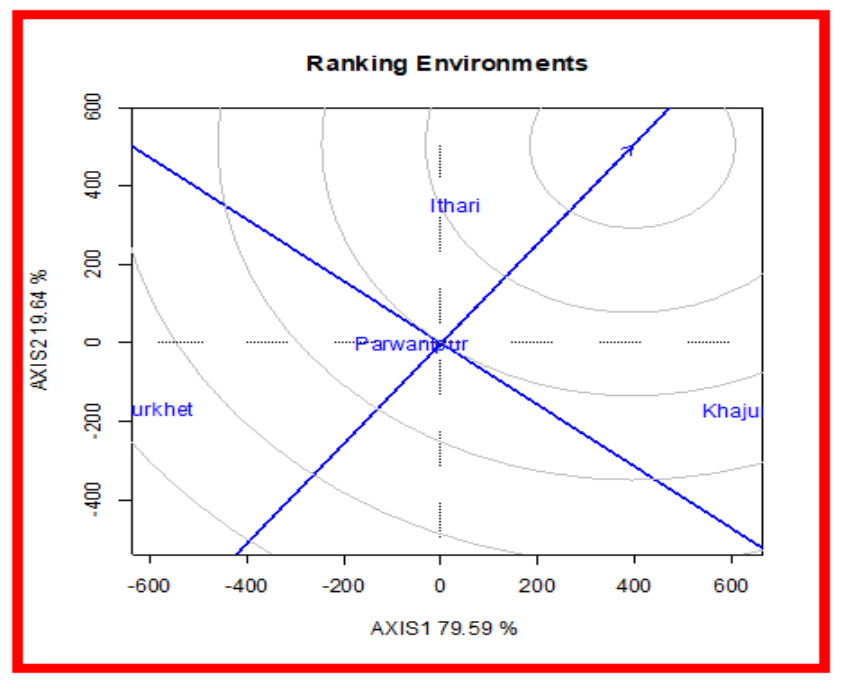

Figure 3: Ranking of genotypes based on discriminating.

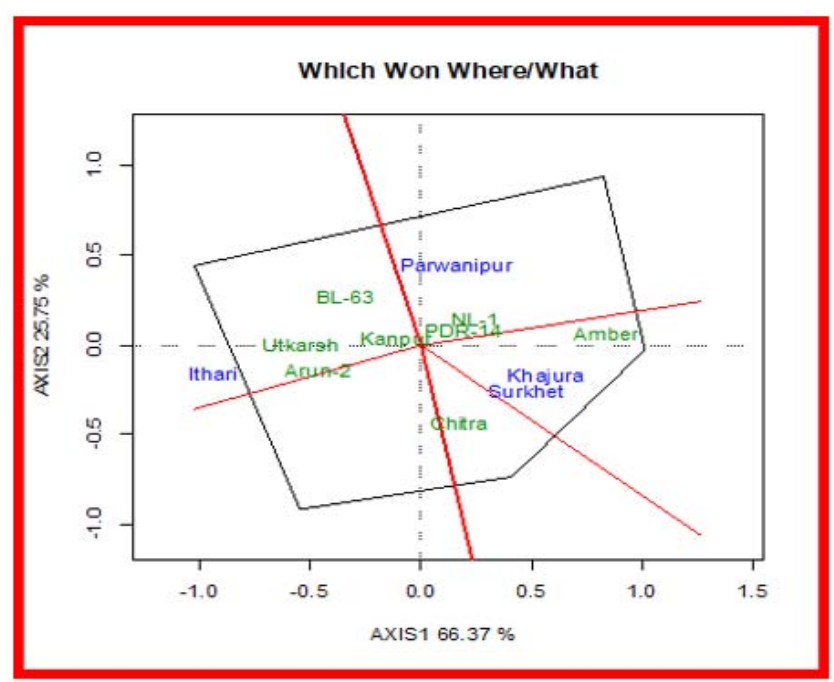

Figure 4: Genotypes with specific environment and representativeness of the average environment.

\section{Conclusion}

The combined ANOVA showed that the highly significant differences among the genotypes and locations in the quantitative traits like Days to $50 \%$ flower, Days to maturity, Plant height, hundred seed weight and grain yield. However the effect of GxE interaction was not found in Days to 50\% flower, Days to maturity and Grain yield. Overall mean performances in terms of grain yield over the years and across the location showed that the genotype PDR-14 (1862 $\left.\mathrm{kgha}^{-1}\right)$ produced the highest yield followed by Utkarsh $\left(1698 \mathrm{kgha}^{-1}\right)$ and Amber (1666 $\left.\mathrm{kgha}^{-1}\right)$. Genotype PDR-14 gave 12-35\% higher yield among the genotypes and its stability analysis test also indicated that PDR-14 was found a highly stable across the environments and over the years. Variegated red kidney shape seed, white flowers along with dwarf and glabrous leaf pubescence is the Distinctness, Uniformity and Stability (DUS) testing trait of the PDR-14 and recommended for terai/inner terai to high hills. 


\section{Acknowledgements}

The authors are highly acknowledged to the NARC Management team for providing financial support to the research. We are grateful to National Genetic Resources Centre (Gene bank), Khumaltar for supplying the genetic materials of grasspea. We wish to express our sincere gratitude to those subordinated whose efforts and cooperation made this work possible.

\section{References}

1. Broughton WJ, Hernández G, Blair M, Beebe S, Gepts P and Vanderleyden J. Beans (Phaseolus spp.) - model food legumes. Plant and Soil. 2003; 252 $55-128$.

2. Ocampo $\mathrm{CH}$, Martin JP, Sánchez-Yélamo MD, Ortiz JM and Toro O. Tracing the origin of Spanish common bean cultivars using biochemical and molecular markers. Genetic Resources and Crop Evolution. 2005; 52: 33-40.

3. KC RB, BK Joshi and SP Dahal. Diversity analysis and physico-morphologica characteristics of indigenous germplasm of lablab bean. Journal of Nepal Agricultural Research Council. 2016; 2: 15-21.

4. Joshi BK, AK Acharya, D Gauchan and MR Bhatta. Agrobiodiversity status and conservation options and methods. In: Conservation and Utilization of Agricultural Plant Genetic Resources in Nepal (BK Joshi, HB KC and AK Acharya, eds). Proceedings of $2^{\text {nd }}$ National Workshop, Dhulikhel; NAGRC FDD, DoA and MoAD; Kathmandu, Nepal. 2017a: 21-38.

5. Neupane RK, R Shrestha, ML Vaidya, EM Bhattarai and R Darai. Agro morphological diversity in common bean (Phaseolus vulgaris L.) landraces of Jumla, Nepal. In Proceedings of the Fourth International Food Legumes Research Conference New Delhi, India 2008: 639-648.
6. Muchui MN, A Ndegwa, S Wachiuri, B Muthama and J Kimamira. Postharvest evaluation of introduced French bean (Phaseolus vulgaris L.) varieties. African Journal of Horticultural Science. 2008; 1: 116-120.

7. Shrestha R, RK Neupane and NP Adhikari. Status and Future Prospects of Pulses in Nepal. In: Regional Workshop on Pulse Production held at Nepal Agricultural Research Council (NARC), Kathmandu. 2011; 24-25.

8. Neupane RK and ML Vaidya. Development of improved production technology of Phaseolus beans to the hills of mid-western Nepal. In: Proceedings of the First Stakeholders' Meeting. NGLRP, Rampur. 2002: 5-11.

9. Annual Report 2015, GLRP, Khajura

10. Annual Report 2016, GLRP, Khajura

11. Annual Report 2017, GLRP, Khajura

12. Chhetri A and A Bhatta. Agro-Morphological Variability Assessment of Common Bean (Phaseolus vulgaris L.) Genotypes in High Hill Jumla, Nepal. International Journal of Environment, Agriculture and Biotechnology. 2017; 2: 3110-3115.

13. Chirwa $R$ and M Phiri. Factors that influence demand for beans in Malawi. CIAT Online Library. 2015.

14. Stoilova T, G Pereira, MM de Sousaand and V Carnide. Diversity in common bean landraces (Phaseolus vulgaris $L$.) from Bulgaria and Portugal. Journal of Central European Agriculture. 2006; 6: 443-448.

15. Chavez-Servia JL, E Heredia-Garcia, N Mayek-Perez, EN Aquino-Bolanos, S Hernandez-Delgado, JC Carrillo Rodriguez, et al. Diversity of common bean (Phaseolus vulgaris L.) landraces and the nutritional value of their grains. Grain Legumes. In Tech, Rijeka, Croati. 2016: 1-33. 